\title{
Push and Pull Travel Motivations of Chinese University Students to Egypt
}

\author{
Tamer Hamdy Ayad
}

Faculty of Tourism and Hotel Management, Suez Canal University

\begin{abstract}
:
The rapid growth of China's outbound tourism market has attracted a great deal of attention in recent years. However, literature is still sparse in this concern. Despite the long historic relation between Egypt and China, and the great variety of Egyptian tourism products, Egypt gets a small market share from the Chinese outbound tourism market. This paper presents an analysis for the pull and push travel motivations, which affect the Chinese University Students decision to travel for tourism. This analysis in particular will highlight the push and pull motivations of the potential travellers of Chinese universities students and give a helping hand to the Egyptian decision makers to assess and rebuild an Egyptian Tourism Marketing Strategy towards Chinese university student market segment.
\end{abstract}

Key Words: Push Motivations, Pull Motivations, China's outbound tourism, Student Travel, Chinese university students.

\section{Introduction:}

China is becoming the largest source market of international travel. It is estimated that China overtook the US as the largest source of international travel spending in 2014 ( Oxford Economics, 2013 ). In 2014 China's yearly outbound tourists reached 117 million, with an increase of $19.16 \%$ over 2013 ( COTRI, 2015 ). The trend of Chinese outbound tourist is changing from sightseeing to experience, from brand to lifestyle. Now, they are attracted by new activities, places, products, new times of the year and different kinds of business. ( COTRI, 2016a ). So all tourism destinations are very interested in meeting the trends of this new market to get a big share for both short and long term ( Latham, 2011 ).

Although, Egypt has a long political, cultural and diplomatic relation with China, and enjoys good reputation as a tourism destination, its share from the Chinese outbound tourism market is small. So the objective of this paper is to analyze the push and pull motivations of the potential travelers from Chinese university students, which influence their final decision to travel for tourism to Egypt. this analysis might help decision makers and marketers to brand Egypt as a youth tourism destination and increase demand among the potential travelers from Chinese university students.

\section{Definitions of Student and Youth Tourism:}

The World Youth Student \& Educational Travel Confederation and United Nation World Tourism Organization revealed some main differences in the age ranges used to define youth tourism. These ranges in some cases cover the 16-24 age group; in some cases, 16-29 age group and in others 16-35 age group. These differences mirror that the concept of the term "youth" is hard to relate to age, as young people may delay their marriage and family formation, entry into work, and seniors strive as much as possible to stay young. This emphasizes that youth travel is not just a question of demographics, but increasingly a travel pattern ( UNWTO and WYSE Travel Confederation, 2005 ).

Therefore, there is a wide variety of definitions related to student and youth tourism in use, with little consistency in terms of age ranges. This variety of definitions is partially attached to the different ways in which youth tourism is characterized:

1- As an age group, generally covering young people between the ages of 15 and 26, but with widely varying limits.

2- As a niche-market attached to a particular travel style, such as adventure travel, language study, independent travel, work exchange and backpacking.

3- Student travel for the specific purpose of study, is becoming more and more significant, which push a growing number of destinations to try to attract this profitable market.

4- As a way for international exchange, peace and understanding. 
To cover all of these different types of market niches, we need to develop a more widely applicable definition of youth travel. The definition proposed by WYSE Travel Confederation is "Youth travel includes all independent trips for periods of less than one year by people aged 16-29 which are motivated, in part or in full, by a desire to experience other cultures, build life experience and/or benefit from formal and informal learning opportunities outside one's usual environment" ( WTO, 2008 ).

The above mentioned definition of WYSE conforms to the UNWTO definition of tourism, which is "the activities of persons travelling to and staying in places outside their usual environment for not more than one consecutive year for leisure, business and other purposes". The UNTWO defined the term of "usual environment of a person" as his home and place of work or study, or other places frequently visited. In the WYSE Travel Confederation definition, the term "independent trip" refers to travelling independently without a parent or guardian ( WTO, 2008 ).

\section{The Value of Youth Travel Market:}

Youth travel is a growing segment of the global travel industry, young people around the world are travelling more, spending more and exploring new destinations. Young people represent $20 \%$ of the total global travel market and the average cost of a trip by a young person amounted to US\$ 910 . The number of international trips by young people might increase from 200 million trips a year at present to 300 million by 2020 . Fewer than a half (45\%) of young people now travel on holidays, while $38 \%$ travel for educational purposes. There is also a significant number (15\%) travelling for work experience purposes while about $5 \%$ travel for volunteer projects ( UNWTO and WYSE Travel Confederation, 2013 ).

Youth tourism has other important impacts besides its importance in terms of tourism volume and expenditure; youth tourism is a means of increasing knowledge of one's own and other cultures. The travel style of young people can also bring important benefits to the destination because young people tend to stay in local accommodation and spend money. This increases their direct impact on the economy compared with most other travelers, Also young travelers are considered as the pioneers of new tourism destinations, as they are opening them up for more traditional forms of tourism ( UNWTO and WYSE Travel Confederation, 2005 ).

Since young travelers are among the first explorers of new places, they can play an important role in the development of a destination's tourism industry. Today's young travelers will become future travelers with a significant amount of discretionary income to be spent on travel. Furthermore,, satisfied youth travelers can become a future target market as they represent potential returning visitors ( Reisinger \& Mavondo, 2002 ). So investment in youth tourism markets is an investment in the future. Young people who have positive travel experiences are likely to later return to destinations they have been there, thereby bringing an important element of repeat visitation and increased tourism expenditure.

\section{Chinese Youth Travelers:}

Younger Chinese people in particular are sophisticated, and the growing appetite for interesting Western brands, famous historic locations and art galleries testify to that. They seek respect and global integration, they want to be part of it all and they work hard - many at international firms as well as in entrepreneurial domestic companies. For them, travel is an important part of self expression, and how they spend their valuable time is part of demonstrating who they are. So, as it turns out, Chinese youth are not so very different from young people allover the world ( UNWTO \& WYSE Travel Confederation, 2012 ). Table ( 1) presents the characteristics of Chinese young adults.

Table ( 1 ): Characteristics of Chinese Young Adults

\begin{tabular}{|c|l|l|l|}
\hline \multicolumn{1}{|c|}{ Items } & \multicolumn{1}{|c|}{$\begin{array}{c}\text { China's Eldest Child: } \\
\text { '70s }\end{array}$} & $\begin{array}{c}\text { China's Middle Child: } \\
\text { '80s }\end{array}$ & \multicolumn{1}{c|}{$\begin{array}{c}\text { China's Youngest } \\
\text { Child: '90s }\end{array}$} \\
\hline Key Focus in Life & $\begin{array}{l}\text { Responsibility \& } \\
\text { Happiness }\end{array}$ & Fun & Excitement \\
\hline
\end{tabular}




\begin{tabular}{|c|c|c|c|}
\hline Core Values & Family & Friends & Self \\
\hline Internet Value & Time Saver & Social Arena & Extension of Self \\
\hline Outlook on Trends & Follow Trends & Choose Trends & Create Trends \\
\hline Online Content & Collecting Information & Sharing Information & Creating Information \\
\hline $\begin{array}{l}\text { Communications } \\
\text { Strategy }\end{array}$ & Nothing overwhelming & Accessible and trendy & $\begin{array}{l}\text { High level of } \\
\text { interaction }\end{array}$ \\
\hline $\begin{array}{l}\text { Engagement } \\
\text { Strategy }\end{array}$ & Information & Peer involvement & Self expression \\
\hline Friends & $\begin{array}{l}\text { Make friends with } \\
\text { those that have power } \\
\text { and influence }\end{array}$ & $\begin{array}{l}\text { Make friends with } \\
\text { those that share the } \\
\text { same interests }\end{array}$ & $\begin{array}{l}\text { Make friends with } \\
\text { those who have } \\
\text { tattoos }\end{array}$ \\
\hline Money & Have Savings & Have Debt & Have Daddies \\
\hline Financial Pressure & $\begin{array}{l}\text { Demands from } \\
\text { children, spouses and } \\
\text { parents }\end{array}$ & $\begin{array}{l}\text { Ignoring pressure and } \\
\text { live in the now }\end{array}$ & $\begin{array}{l}\text { Pampered by parents } \\
\text { and grandparents }\end{array}$ \\
\hline Discussion Topics & $\begin{array}{l}\text { Topics that relate to } \\
\text { everyday life: } \\
\text { - Seasonal fashion } \\
\text { - Property prices }\end{array}$ & $\begin{array}{l}\text { Topics that make one } \\
\text { get ahead: } \\
\text {-Career } \\
\text { - Trends }\end{array}$ & $\begin{array}{l}\text { Exciting topics to be } \\
\text { shared: } \\
\text {-Sensations } \\
\text { - Gossip }\end{array}$ \\
\hline
\end{tabular}

Source: UNWTO \& WYSE Travel Confederation, 2012.

The China's outbound tourism is growing exponentially within the last few years, and the Chinese travelers are fast becoming one of the tourism industry's major opportunities, as 135 million Chinese travelers spent US\$ 229 billion in 2015. So all international tourism destinations are keen to understand how to meet the needs of this new market to get more share in the short and long term (COTRI, 2015 ). The breakdown of foreign travel from China by age group reported by different sources varies significantly, depending on the survey sample and the different criteria of measurement. Official statistics show that Chinese outbound travelers born post 1980s make up 56.21\% of all trips, while travelers born post 1990s account for $11.27 \%$ and travelers born post 1970s account for 26.24\% ( WTCF, 2014 ). Figure ( 1 ) presents the age profile of outbound Travelers from China during 2014:

Figure ( 1 ): Age Profile of Outbound Travelers from China, 2014

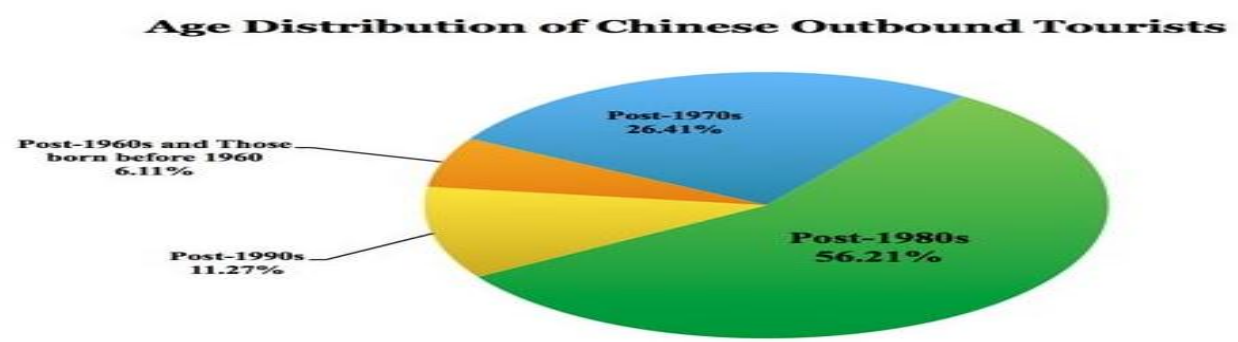

Source: WTCF, 2014. 


\section{Share of Egypt from China's outbound market:}

According to the published figures of Egyptian Ministry of Tourism, the share of Egypt from the China's Outbound Market doesn't commensurate with the long relation between Egypt and China, the great diversity of Egyptian tourism products, and the Large size of the outbound tourism market of China. In 2015, the number of Chinese tourists visiting Egypt has risen considerably from 60,000 in 2014 to 135,000 (COTRI, $2016 b)$.

\section{Travel Motivation Forces:}

The tourist motivation is defined as a global integrating network of various biological and cultural forces, which gives value and direction to the travel choices, behavior and experience ( Pearce et al, 1998 ). Motivation has various aspects as psychological, biological and social. Motivation is associated with internal and external forces, which show how tourists are pushed by motivation variables and how they are pulled by destination attributes to take the travel decision at the end ( Uysal \& Hagan, 1993 ). The push factors are used to explain the desire of a person to go for tourism, while the pull factors are used to explain the selection of destination ( Goossens, 2000 ).

The push and pull factors theory states that people are firstly pushed by the internal factors or emotional factors such as the need to escape, to relax, for adventure, for knowledge and so on. After having been pushed by internal factors, they are pulled by external factors such as the natural, outdoor activities, historical attractions and so on ( Baloglu and Uysal, 1996 ).

Yoon and Uysal (2005) stated that each tourist destination offers various tourism products and services to attract tourists to visit it. It is very important for the destination stakeholders to know the reasons which drive tourists to choose or not to choose their destination. So the analysis of tourist motivation is considered as attempts to extend the theoretical and empirical evidence on the causal relationship among the push and pull motivations.

The marketing planners are interested in understanding why people choose a particular destination, in order to improve the income from tourism industry and to determine marketing segments ( Hanafiah et al, 2008 ). Analysis of motivation factors could reveal the mechanism by which people set goals for the choice of their destination, and how these goals are reflected in their final destination choice and their travel behavior. Also this analysis could provide the tourism planners, tour operators, and other stakeholders and decision makers with a better understanding of the needs, goals and expectations of the tourists. Such an understanding is very important to enhance the creation of travel products to meet the needs and expectations of tourists ( Mansfeld, 1992 ).

\section{Methodology:}

A close-ended questionnaire was designed to assist to identify the push and pull motivations of the Chinese university students regarding travel to Egypt. The Questionnaire consists of three parts; the first part surveys personal and demographic factors; the second concerns the push motivations for Chinese university students to travel abroad, and the third one concerns the pull motivations for Chinese university students to travel to Egypt. For the push and pull motivations, a five-point Likert scale was used, ranging from strongly disagree (1) to strongly agree (5).

In order to ensure the reliability and validity of the questionnaire, a pilot test targeting some university students, was undertaken to examine whether the planned measures of variables were meaningful to respondents.

The collected data were analyzed with the aid of SPSS version 17 and Excel Spread Sheet in Office 2007.

\section{Analysis and Results:}

The questionnaires were distributed to a random sample of 485 Chinese university students of 9 universities in 7 different cities in China during Sept, 2014 to Nov, 2015 (Table 2). Only 17 questionnaires were excluded. 
Table ( 2 ): Universities, Cities and Number of Respondents

\begin{tabular}{|c|c|c|c|c|}
\hline University & City & Province & $\begin{array}{c}\text { No. of } \\
\text { Respondents }\end{array}$ & $\begin{array}{l}\% \text { of } \\
\text { Sample }\end{array}$ \\
\hline Beijing Jiaotong University & Beijing & Beijing & 127 & 27.1 \\
\hline Beijing Institute of Technology & Beijing & Beijing & 39 & 8.3 \\
\hline $\begin{array}{c}\text { Central University of Finance and } \\
\text { Economics }\end{array}$ & Beijing & Beijing & 53 & 11.3 \\
\hline Shanghai Astronomical Observatory & Shanghai & Shanghai & 66 & 14.1 \\
\hline Zhejiang University & Hangzhou & Zhejiang & 50 & 10.7 \\
\hline (2)Jiangnan University & Wuxi & Jiangsu & 18 & 3.9 \\
\hline Tongji Medical University & Wuhan & Hubei & 49 & 10.5 \\
\hline Central South University & Changsha & Hunan & 38 & 8.1 \\
\hline Northwest A \& F University & Yangling & Shaanxi & 28 & 6 \\
\hline Total & & & 468 & 100 \\
\hline University & City & Province & $\begin{array}{c}\text { No. of } \\
\text { Respondents }\end{array}$ & $\begin{array}{l}\% \text { of } \\
\text { Sample }\end{array}$ \\
\hline Beijing Jiaotong University & Beijing & Beijing & 127 & 27.1 \\
\hline Beijing Institute of Technology & Beijing & Beijing & 39 & 8.3 \\
\hline $\begin{array}{c}\text { Central University of Finance and } \\
\text { Economics }\end{array}$ & Beijing & Beijing & 53 & 11.3 \\
\hline Shanghai Astronomical Observatory & Shanghai & Shanghai & 66 & 14.1 \\
\hline Zhejiang University & Hangzhou & Zhejiang & 50 & 10.7 \\
\hline
\end{tabular}

Table ( 3 ) presents the socio-demographic background of the sample of 468 university students. Males represent $58.1 \%$ and Females represent $41.9 \%$. The majority of respondents' ages ( $61.5 \%$ ) were between 17 to 20 Years. Most of the students are Bachelor students ( $62.2 \%$ ), Master Degree Students represent ( $25.5 \%$ ) and $\mathrm{PhD}$ candidates represent ( $12.2 \%$ ). The annual income varies from less than RMB 30,000 (\$4800) per year to RMB 50,000 (\$8000). 43.8\% of the respondents are living with family, 34\% are living in a State Dormitory and 16\% in Private Dormitory. Regarding visiting Egypt before, the majority of the respondents ( $98.3 \%$ ) didn’t visit Egypt before. 
Table ( 3 ): Socio-demographic Characteristics of the Sample

\begin{tabular}{|c|c|c|}
\hline Variables & Frequency & $\%$ \\
\hline \multicolumn{3}{|l|}{ 1- Gender: } \\
\hline a- Male & 272 & 58.1 \\
\hline b- Female & 196 & 41.9 \\
\hline \multicolumn{3}{|l|}{ 2- Age: } \\
\hline a- 17 - less than 20 Years. & 288 & 61.5 \\
\hline b- 21 - less than 24 Years. & 46 & 9.8 \\
\hline c- 25 - less than 28 Years. & 78 & 16.7 \\
\hline d- More than 28 Years. & 56 & 12 \\
\hline \multicolumn{3}{|l|}{ 3- Educational Status: } \\
\hline a- Bachelor Student & 291 & 62.2 \\
\hline b- Master Degree Student & 120 & 25.5 \\
\hline c- PhD. Degree Student & 57 & 12.2 \\
\hline d- Others & 0 & 0 \\
\hline \multicolumn{3}{|l|}{ 4- Annual Income: } \\
\hline a- Less than RMB 30,000 & 221 & 47.2 \\
\hline b- RMB 30,001 to 40,000 & 144 & 30.8 \\
\hline c- $\mathrm{RMB} 40,001$ to 50,000 & 32 & 6.8 \\
\hline d- More than RMB 50,000 & 71 & 15.2 \\
\hline \multicolumn{3}{|l|}{ 5- Residence: } \\
\hline a- Family & 205 & 43.8 \\
\hline b- Private Dormitory & 75 & 16 \\
\hline c- State Dormitory & 159 & 34 \\
\hline d- With friends & 29 & 6.2 \\
\hline \multicolumn{3}{|l|}{ 6- Visit to Egypt before: } \\
\hline a- Yes & 8 & 1.7 \\
\hline b- No & 460 & 98.3 \\
\hline
\end{tabular}

Understanding how customers acquire information is important for marketing management decisions. This is especially true for services, travel and tourism products. The questionnaire includes a question about the source of information about Egypt and the respondents were allowed to choose more than one answer. Table ( 4 ) presents the frequency of the responses of Chinese university students about the source of their information about Egypt as a tourism destination. 
Table ( 4 ): Source of Information about Egypt

\begin{tabular}{ccc}
\hline \hline Source & Frequency & \% of the Sample \\
\hline \hline TV & 384 & 82.1 \\
\hline Books \& Magazines & 286 & 61.1 \\
\hline Egyptian Web Sites & 9 & 1.9 \\
\hline Chinese web Sites & 180 & 38.5 \\
\hline Travel Agents & 22 & 4.7 \\
\hline Brochures & 36 & 7.7 \\
\hline Friends \& Relatives & 192 & 41 \\
\hline
\end{tabular}

The results of table ( 4 ) indicate that TV, Books \& Magazines and Chinese web Sites are the most highlighted by the respondents as sources of information about Egypt. Therefore, the decision makers, planners, and marketers in Egypt should focus on the above mentioned types of marketing tools when targeting the potential tourists of Chinese university students.

To identify the push motivations of Chinese university students to travel, the questionnaire contains 15 different push motivations, such as desire to know about other cultures, desire to have new life experience, relaxation, social interaction, searching new business opportunities, escape from daily life, shopping and so on. The survey respondents were asked to rank their motivations on a 5-point Likert scale, starting with strongly disagree (1) to strongly agree (5).

Analysis of Push Motivations (Table 5) shows that the most important four push motives that scored above 4.0 on the five-point Likert scale were to know about other cultures ( 4.255 ), meet with new people ( 4.244 ), escape from daily routine life ( 4.155 ), and searching new business opportunities ( 4.244 ).

Table ( 5 ): Mean Scores of push motivations as expressed by Chinese university students

\begin{tabular}{lcccc}
\hline \multicolumn{1}{c}{ Push Motivations } & Min. & Max. & Mean & $\begin{array}{c}\text { Std } \\
\text { Deviation }\end{array}$ \\
\hline \hline Know about other cultures & 3 & 5 & 4.255 & 0.578 \\
\hline Meet with new people & 3 & 5 & 4.244 & 0.567 \\
\hline Escape from daily routine life & 3 & 5 & 4.155 & 0.578 \\
\hline Searching new business opportunities & 3 & 5 & 4.244 & 0.567 \\
\hline Enjoy Shopping & 1 & 5 & 3.933 & 0.909 \\
\hline Relaxation & 2 & 5 & 3.655 & 0.823 \\
\hline
\end{tabular}


To identify the pull motivations of Chinese university students to Egypt, the questionnaire contains 15 different pull motivations, such as Egyptian Pyramids, Historical Sites, Beautiful Beaches, River Nile, Nile Cruises, Kind People, Theme Parks, Reliable Weather, Safety, Night Life, Variety of Food, Variety of sightseeing tours and so on. The respondents were asked to rank their pull motivations on a 5-point Likert scale, starting with strongly disagree (1) to strongly agree (5).

Analysis of Pull Motivations (Table 6) shows that the most important five pull motives for Chinese to travel to Egypt, that scored above 4.0 on the five-point Likert scale were The Egyptian Pyramids ( 4.255 ), River Nile ( 4.255 ), Business Opportunities ( 4.244 ), Historical Sites ( 4.155 ), and Weather ( 4.188 ).

Table ( 6 ): Mean Scores of pull motivations as expressed by Chinese university students

\begin{tabular}{lcccc}
\hline \multicolumn{1}{c}{ Pull Motivations } & Min. & Max. & Mean & $\begin{array}{c}\text { Std } \\
\text { Deviation }\end{array}$ \\
\hline \hline The Egyptian Pyramids & 3 & 5 & 4.255 & 0.578 \\
\hline River Nile & 3 & 5 & 4.255 & 0.578 \\
\hline Business Opportunities & 3 & 5 & 4.244 & 0.578 \\
\hline Historical Sites & 3 & 5 & 4.155 & 0.567 \\
\hline Weather & 3 & 5 & 4.188 & 0.597 \\
\hline Beautiful Beaches & 1 & 5 & 3.933 & 0.909 \\
\hline Variety of sightseeing tours & 2 & 5 & 3.655 & 0.823 \\
\hline Safety & 2 & 5 & 3.655 & 0.823 \\
\hline
\end{tabular}

To have clearer image and deeper analysis, the push and pull motivations were examined with respect to gender, age groups, and educational status.

Table (7): Means of Push Motivations with respect to gender

\begin{tabular}{llccc}
\hline \multicolumn{1}{c}{ Push Motivations } & $\begin{array}{c}\text { Male } \\
\text { Mean }\end{array}$ & Rank & $\begin{array}{c}\text { Female } \\
\text { Mean }\end{array}$ & Rank \\
\hline \hline Know about other cultures & 4.245 & 2 & 4.365 & 1 \\
\hline Meet with new people & 4.211 & 3 & 4.122 & 3 \\
\hline Escape from daily routine life & 4.021 & 4 & 4.155 & 2 \\
\hline Searching new business opportunities & 4.395 & 1 & 2.824 & 5 \\
\hline Enjoy Shopping & 2.943 & 6 & 4.365 & 1 \\
\hline Relaxation & 3.822 & 5 & 4.022 & 4 \\
\hline
\end{tabular}

From Table (7), it could be observed that the most important push motivations for males to travel abroad were searching for new business opportunities (mean score 4.395), know about other cultures (4.245), meet with new people (4.211). For females the motivations were to know about other cultures (4.365), escape from daily routine life (4.155), meet with new people (4.122). 
Table (8): Means of Push Motivations with respect to age groups

\begin{tabular}{lcccccccc}
\hline \multicolumn{1}{c}{$\begin{array}{c}\text { Push } \\
\text { Motivations }\end{array}$} & $\begin{array}{c}\text { Group } \\
\text { "A" } \\
\text { Mean }\end{array}$ & Rank & $\begin{array}{c}\text { Group } \\
\text { "B" } \\
\text { Mean }\end{array}$ & Rank & $\begin{array}{c}\text { Group } \\
\text { "C" } \\
\text { Mean }\end{array}$ & $\begin{array}{c}\text { Rank } \\
\text { "D" } \\
\text { Mean }\end{array}$ & Rank \\
\hline \hline $\begin{array}{l}\text { Know about } \\
\text { other cultures }\end{array}$ & 4.345 & 2 & 4.425 & 1 & 4.255 & 1 & 4.624 & 1 \\
\hline $\begin{array}{l}\text { Meet with } \\
\text { new people }\end{array}$ & 4.345 & 2 & 4.146 & 2 & 4.122 & 3 & 4.024 & 4 \\
\hline $\begin{array}{l}\text { Escape from } \\
\text { daily routine } \\
\text { life }\end{array}$ & 4.122 & 3 & 4.138 & 3 & 4.122 & 3 & 4.346 & 2 \\
\hline $\begin{array}{l}\text { Searching } \\
\text { new business } \\
\text { opportunities }\end{array}$ & 4.422 & 1 & 3.822 & 5 & 2.542 & 5 & 4.122 & 3 \\
\hline $\begin{array}{l}\text { Enjoy } \\
\text { Shopping }\end{array}$ & 3.021 & 5 & 3.822 & 5 & 4.144 & 2 & 3.682 & 5 \\
\hline \begin{tabular}{l} 
Relaxation \\
\hline
\end{tabular} & 3.743 & 4 & 4.021 & 4 & 3.865 & 4 & 4.346 & 2 \\
\hline
\end{tabular}

Group "A": 17- less than 20 Years; Group "B": 21- less than 24 Years; Group "C": 25- less than 28 Years; Group "D": More than 28 Years.

Analysis of Push Motivations with respect to the age groups indicates (Table 8) that the most important push motivations for 17 to less than 20 years old students to travel abroad, were searching for new business opportunities (4.422), "know about other cultures" and "meet with new people" (4.345). For those of 21 to less than 24 years old push motivations to travel abroad were know about other cultures (4.425), meet with new people (4.146).

Again, push motivations for those 25 to less than 28 years old to travel abroad were to know about other cultures (4.255), enjoy shopping (4.144). For students of more than 28 years old, push motivations to travel abroad were know about other cultures (4.624), escape from daily routine life and relaxation (4.346).

Table (9): Means of Push Motivations with respect to the educational status

\begin{tabular}{lcccccc}
\hline \multicolumn{1}{c}{ Push Motivations } & $\begin{array}{c}\text { Group } \\
\text { "A" } \\
\text { Mean }\end{array}$ & Rank & $\begin{array}{c}\text { Group } \\
\text { "B" } \\
\text { Mean }\end{array}$ & Rank & $\begin{array}{c}\text { Group } \\
\text { "C" } \\
\text { Mean }\end{array}$ & Rank \\
\hline \hline Know about other cultures & 4.255 & 2 & 4.642 & 1 & 4.342 & 1 \\
\hline Meet with new people & 4.255 & 2 & 4.642 & 1 & 4.024 & 3 \\
\hline Escape from daily routine & 4.122 & 3 & 4.121 & 2 & 4.244 & 2 \\
\hline
\end{tabular}




\begin{tabular}{lcccccc}
\hline life & & & & & & \\
\hline $\begin{array}{l}\text { Searching new business } \\
\text { opportunities }\end{array}$ & 4.322 & 1 & 4.021 & 3 & 4.024 & 3 \\
\hline Enjoy Shopping & 3.124 & 5 & 3.822 & 4 & 3.824 & 4 \\
\hline Relaxation & 3.833 & 4 & 3.822 & 4 & 4.244 & 2 \\
\hline
\end{tabular}

Group "A": Bachelor Students; Group "B": Master Degree Students; Group "C": PhD. Degree Candidates.

Analysis of Push Motivations in relation to the educational status (Table 9) reveals that the most important push motivations for Chinese bachelor's students to travel abroad were "searching for new business opportunities" with a mean score of 4.322, then "know about other cultures" and "meet with new people" (4.255). For master degree students, push motivations to travel abroad were "know about other cultures" and "meet with new people" (4.642), then "escape from daily routine life" (4.121). For Chinese PhD candidates, the push motivations were "know about other cultures" (4.342), then "escape from daily routine life" (4.244).

Table (10): Means of Pull Motivations with respect to gender

\begin{tabular}{lcccc}
\hline \hline \multicolumn{1}{c}{ Pull Motivations } & $\begin{array}{c}\text { Male } \\
\text { Mean }\end{array}$ & Ranking & $\begin{array}{c}\text { Female } \\
\text { Mean }\end{array}$ & Ranking \\
\hline \hline The Egyptian Pyramids & 4.255 & 1 & 4.255 & 1 \\
\hline River Nile & 4.255 & 1 & 4.255 & 1 \\
\hline Business Opportunities & 4.242 & 2 & 3.842 & 4 \\
\hline Historical Sites & 3.982 & 3 & 4.212 & 2 \\
\hline Weather & 3.943 & 4 & 3.365 & 7 \\
\hline Beautiful Beaches & 3.822 & 5 & 4.022 & 3 \\
\hline Variety of sightseeing tours & 3.732 & 6 & 3.424 & 5 \\
\hline Safety & 3.732 & 6 & 3.411 & 6 \\
\hline
\end{tabular}

As for the Pull Motivations in relation to gender table (10) shows that the most important pull motivations for male Chinese university students to travel to Egypt were the Egyptian Pyramids and River Nile with a mean score of 4.255, then business opportunities (4.242). Meanwhile the most important pull motivations for females were also Egyptian Pyramids and River Nile (4.255), then historical sites (4.212).

Table (11): Means of Pull Motivations with respect to the age groups

\begin{tabular}{lcccccccc}
\hline $\begin{array}{c}\text { Push } \\
\text { Motivations }\end{array}$ & $\begin{array}{c}\text { Group } \\
\text { "A" } \\
\text { Mean }\end{array}$ & Rank & $\begin{array}{c}\text { Group } \\
\text { "B" } \\
\text { Mean }\end{array}$ & Rank & $\begin{array}{c}\text { Group } \\
\text { "C" } \\
\text { Mean }\end{array}$ & Rank & $\begin{array}{c}\text { Group } \\
\text { "D" } \\
\text { Mean }\end{array}$ & Rank \\
\hline $\begin{array}{l}\text { The Egyptian } \\
\text { Pyramids }\end{array}$ & 4.255 & 1 & 4.255 & 1 & 4.255 & 1 & 4.255 & 1 \\
\hline
\end{tabular}




\begin{tabular}{|c|c|c|c|c|c|c|c|c|}
\hline River Nile & 4.255 & 1 & 4.255 & 1 & 4.255 & 1 & 4.255 & 1 \\
\hline $\begin{array}{l}\text { Business } \\
\text { Opportunities }\end{array}$ & 3.824 & 6 & 3.944 & 4 & 4.122 & 4 & 4.255 & 1 \\
\hline $\begin{array}{l}\text { Historical } \\
\text { Sites }\end{array}$ & 4.155 & 2 & 4.155 & 2 & 4.155 & 3 & 4.155 & 2 \\
\hline $\begin{array}{l}\text { Reliable } \\
\text { Weather }\end{array}$ & 4.022 & 3 & 3.944 & 4 & 4.212 & 2 & 3.868 & 3 \\
\hline $\begin{array}{l}\text { Beautiful } \\
\text { Beaches }\end{array}$ & 3.942 & 4 & 4.021 & 3 & 3.624 & 6 & 3.824 & 4 \\
\hline $\begin{array}{l}\text { Variety of } \\
\text { sightseeing } \\
\text { tours }\end{array}$ & 3.655 & 7 & 3.482 & 6 & 3.746 & 5 & 3.655 & 5 \\
\hline Safety & 3.842 & 5 & 3.655 & 5 & 3.432 & 7 & 3.524 & 6 \\
\hline
\end{tabular}

Group "A": 17- less than 20 Years; Group "B": 21- less than 24 Years; Group "C": 25- less than 28 Years; Group "D": More than 28 Years.

The results of pull motivations with respect to the age groups (Table 11) shows that the most important pull motivations for Chinese university students of 17 to less than 20 years old to travel to Egypt, were the Egyptian Pyramids and River Nile (4.255), then historical sites (4.155). For the aged group of 21 to less than 24 years old the pull motivations were the Egyptian Pyramids and River Nile (4.255), then historical sites (4.155).

Meanwhile, pull motivations for the aged group of 25 to less than 28 years to travel to Egypt were the Egyptian Pyramids and River Nile (4.255), then weather (4.212). For the aged group of more than 28 years, pull motivations to travel to Egypt were the Egyptian Pyramids, River Nile and business opportunities (4.255), then historical sites with a mean score of 4.155 .

Table (12): Means of Pull Motivations with respect to the educational status

\begin{tabular}{lcccccc}
\hline \hline \multicolumn{1}{c}{ Push Motivations } & $\begin{array}{c}\text { Group } \\
\text { "A" } \\
\text { Mean }\end{array}$ & Rank & $\begin{array}{c}\text { Group } \\
\text { "B" } \\
\text { Mean }\end{array}$ & Rank & $\begin{array}{c}\text { Group } \\
\text { "C" } \\
\text { Mean }\end{array}$ & Rank \\
\hline The Egyptian Pyramids & 4.224 & 1 & 4.346 & 1 & 4.188 & 2 \\
\hline River Nile & 4.198 & 2 & 4.346 & 1 & 4.188 & 2 \\
\hline Business Opportunities & 4.198 & 2 & 4.248 & 3 & 4.188 & 2 \\
\hline Historical Sites & 4.198 & 2 & 4.268 & 2 & 4.218 & 1 \\
\hline Reliable Weather & 4.188 & 3 & 4.188 & 4 & 4.188 & 2 \\
\hline
\end{tabular}




\section{Tamer Hamdy Ayad}

\begin{tabular}{lllllll}
\hline Beautiful Beaches & 3.989 & 4 & 3.462 & 6 & 3.212 & 5 \\
\hline $\begin{array}{l}\text { Variety of sightseeing } \\
\text { tours }\end{array}$ & 3.868 & 5 & 3.244 & 7 & 3.546 & 4 \\
\hline Safety & 3.655 & 6 & 3.655 & 5 & 3.655 & 3 \\
\hline
\end{tabular}

Group "A": Bachelor Student; Group "B": Master Degree Student; Group "C": PhD. Candidates.

Analysis of pull motivations with respect to educational status (Table 12) shows that the most important pull motivations for Chinese bachelor's students to travel to Egypt were the Egyptian Pyramids (4.224), then River Nile, business opportunities and historical sites with a mean score of 4.198 for each. For Chinese master degree students the motivations were the Egyptian Pyramids and River Nile with a mean score of 4.346, then historical sites (4.268). Meanwhile, for Chinese $\mathrm{PhD}$ candidates, pull motivations to travel to Egypt were historical sites (4.218), then the Egyptian Pyramids, River Nile, business opportunities and weather with a mean score of 4.188 for each.

\section{Conclusion:}

- TV, Books, Magazines and Chinese web Sites are the most influential source of information for Chinese university students.

- The most important push motivations which affect the choice of travelling abroad for the Chinese university students, were to know about other cultures, meet with new people, and escape from daily routine life.

- The most important push motivations which affect the choice of travelling abroad for Chinese university students with respect to gender, were searching for new business opportunities, know about other cultures, and meet new people for male students, and were to know about other cultures, escape from daily routine life, and meet new people for female students.

- The most important push motivations which affect the choice of travelling abroad for Chinese university students with respect to educational status, were searching for new business opportunities, know about other cultures and meet with new people for Chinese bachelor's students, and were to know about other cultures, meet with new people and escape from daily routine life for Chinese master degree students, and were to know about other cultures, and escape from daily routine life for Chinese $\mathrm{PhD}$ candidates.

- The most important pull motivations which affect the choice of the travelling to Egypt for the Chinese university students were "The Egyptian Pyramids", "River Nile", and "Business Opportunities".

- The most important pull motivations which affect the choice of travelling to Egypt for Chinese university students with respect to gender were "the Egyptian Pyramids", "River Nile" and "business opportunities" for males, and "Egyptian Pyramids", "River Nile" and "historical sites" for females.

- The most important pull motivations which affect the choice of travelling to Egypt for Chinese university students with respect to educational status, were the Egyptian Pyramids, River Nile, business opportunities, and historical sites for Chinese bachelor's students, and were the Egyptian Pyramids, River Nile and historical sites for Chinese master degree students, and historical sites, the Egyptian Pyramids, River Nile, business opportunities and weather for Chinese PhD candidates.

\section{Recommendations:}

- The Egyptian Tourism Ministry should exert more efforts to know more about the potential travelers of Chinese university students through marketing research. 
- The Egyptian Tourism Authority and The Egyptian Tourism Office in Beijing should build a special marketing strategy to attract this segment of potential Chinese universities students' travelers, to maximize Egypt's share from Chinese outbound market.

- The Egyptian decision makers and marketers should focus on TV, Books, Magazines and Chinese web Sites, as being the most influential sources of information for Chinese university students.

- The Egyptian tourism planners and marketers, should focus on the most important push and pull motivations which affect the choice of travel to Egypt.

\section{References:}

Baloglu, S. and Uysal, M., (1996), "Market Segment of Push and Pull Motivation: a Canonical Correlation Approach", International journal of Contemporary Hospitality Management, 8 (3), 32-38.

COTRI (2015), " COTRI Market Report ", China Outbound Tourism Research Institute, Beijing.

COTRI (2016a) [ http://china-outbound.com/ ] visited on Jan 28,2016.

COTRI (2016b) [ http://china-outbound.com/2016/01/26/arab-nations-count-on-china-to-revive-domestictourism/ ] visited on Feb 15,2016

Goossens, C., (2000), " Tourism information and pleasure motivation ", Annals of Tourism Research, 27(2), 301-321.

Hanafiah, M. H. M; Othman, Z.; Zulkifly, M. I.; Ismail, H. and Jamaluddin, M. R. (2008), " Malaysian Tourists Motivation Towards Outbound Tourism ", University of Technology MARA, Selangor, Malaysia.

Latham, K. (2011), " Blue Paper: How the rise of Chinese tourism will change the face of the European travel industry ", University of London.

Mansfeld, Y. (1992), "From Motivation to Actual Travel. Annals of Tourism Research", 19:399-419.

Oxford Economics ( 2013 ), " The future of Chinese Travel: The Global Chinese Travel Market " A report by Oxford Economics, Tourism Economics, Oxford University's business college.

Pearce, P.; Morrison, A. M. and J. L. Rutledge (1998), " Tourism: Bridges Across Continents ", Sydney: McGraw-Hill.

Reisinger, Y. and Mavondo, F. (2002), "Determinants of Youth Travel Markets' Perceptions of Tourism Destinations" TOURISM ANALYSIS 7(1):55-66.

UNWTO and WYSE Travel Confederation (2013). The Power of Youth Travel. Volume II.

UNWTO \& WYSE Travel Confederation, (2012) “The power of youth travel” Volume II.

UNWTO and WYSE Travel Confederation (2005). The power of youth travel. Volume II.

Uysal, M. and Hagan, L. A. (1993), " Motivations of pleasure travel and tourism", In M. Khan, M. Olsen, \& T. Var (Eds.), Encyclopedia of Hospitality and Tourism (pp. 798-810), New York: Van Nostrand Reinhold.

WTCF (2014) " Beijing fragrant hills tourism summit ", World Tourism Cities Federation, Sep 04 - 05,2014, Beijing.

WTO (2008). Youth Travel Matters - Understanding the Global Phenomenon of Youth Travel. Madrid, Spain. 
Yoon, Y. and Uysal M. (2005), " An examination of the effects of motivation and satisfaction on destination loyalty: a structural model" Tourism Management 26:45-56.

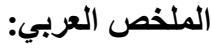

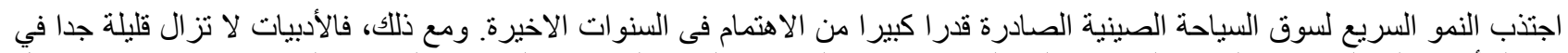

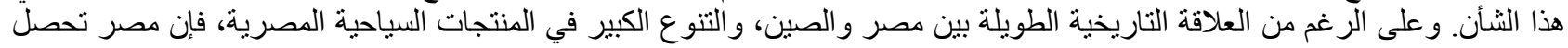

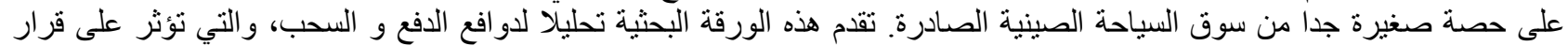

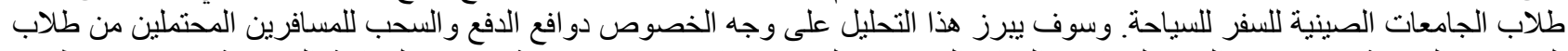

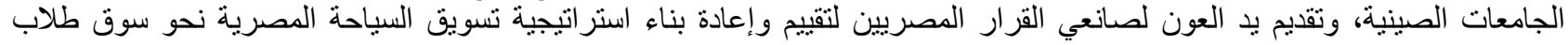


Appendix 1: A copy of the close-ended questionnaire

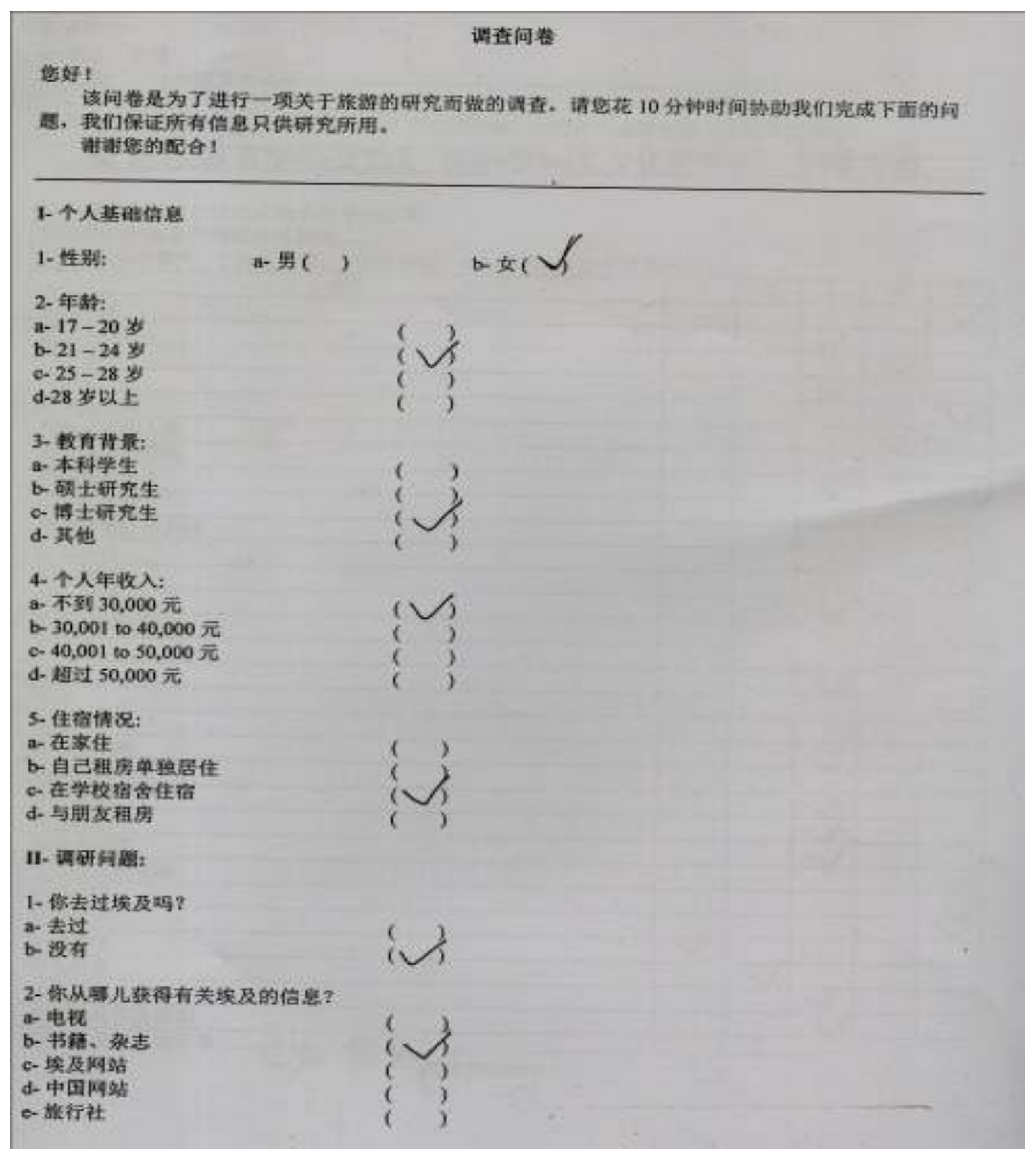




\section{Tamer Hamdy Ayad}
f- 宣传册
g- 觜度、亲何
h- 其位( ) 并请年体说明

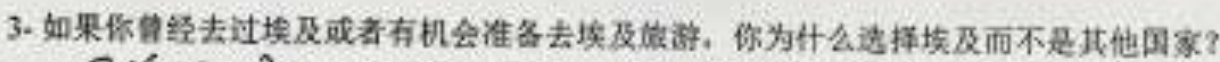

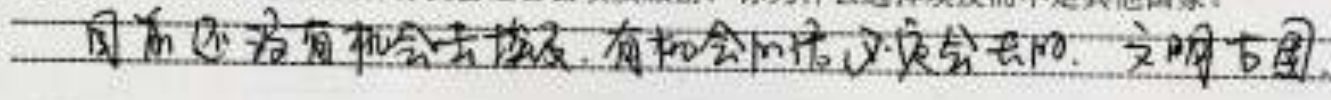

4. 埃及作为瓶泽目的地在你心目中的形里:

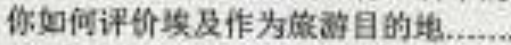

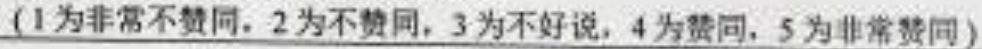

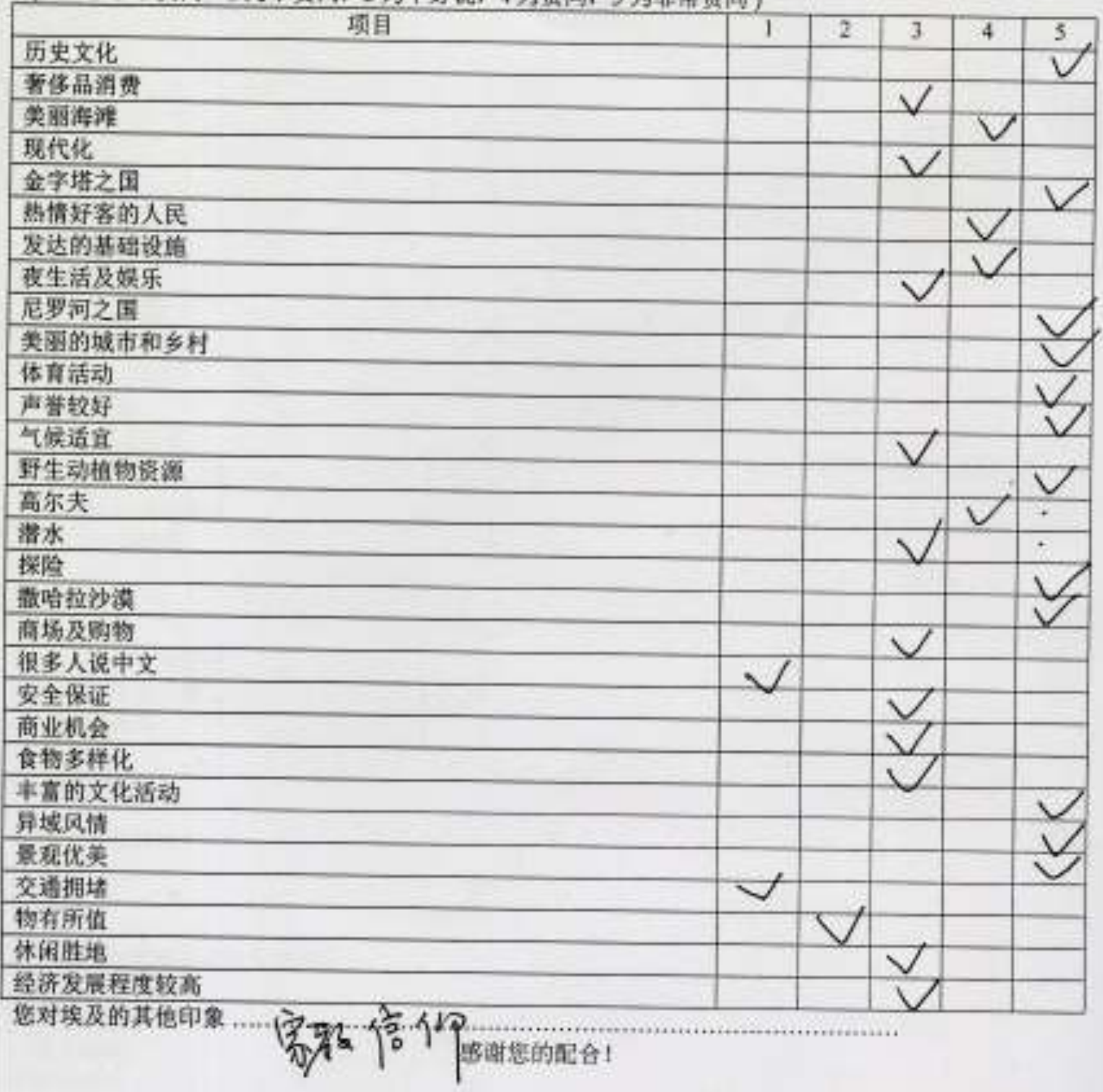

